\title{
10. Struggling Geographies: Rethinking livelihood and locality in Timor-Leste
}

\author{
Sandra Pannell
}

\section{A Geography which Struggles I: Introduction}

The island of Timor could be regarded - to borrow Edward Said's expressionas a 'geography which struggles' (1993:6). Our understanding of this geography is dominated by a discourse of destruction and degradation. Writings about the island and its people commonly talk about the 'Timor tragedy' or the 'Timor problem'. As James Dunn's account reveals, the tragedy of Timor (see Dunn 1983:xi) is a story of gross injustice and local suffering, linked to the dismal failure of the international community to respond to Indonesia's invasion of East Timor in 1974. Since independence in 2002, it seems that 'poverty and unemployment' are contributing to a 'new tragedy' in one of the world's latest nation-states (BBC n.d.).

Timor's 'problem', on the other hand, is said to be an island-wide ecological crisis, caused by swidden agricultural systems and population pressure. ${ }^{1}$ While the notion that local shifting cultivation systems in the 'Outer Islands' were inherently fragile and maladaptive to increasing population was first identified by F. J. Ormeling in 1956, it was Clifford Geertz's study of ecological change in Indonesia that popularised the idea (Geertz 1963). While not intended as such, Geertz's conclusions about swidden agriculture appeared to reinforce existing and overly negative European perceptions of these systems as primarily 'attended by serious deforestation and soil erosion' (Geertz 1963:15-16).

The characterisation of local subsistence systems as 'voracious slash-and-burn agricultural regime[s]', with 'low agrarian production' (McWilliam 2002:1), responsible for Timor's environmental 'problem', has prompted a significant national and international development effort aimed at changing local land-use practices and improving the country's economic circumstances. Yet, as delegates attending Timor-Leste's first conference on 'Sustainable Development and the

\footnotetext{
1 As both Fox (1977) and Friedberg (1977) point out, however, colonial policies and actions in both East and West Timor played an important - often overlooked - role in the creation of this crisis, in symbolic and empirical terms.
} 
Environment', held in Dili in 2001, identified, '400 years of colonization by Portugal, and 25 years of occupation by Indonesia' (Anderson and Deutsch 2001:11; see also McWilliam 2003:308) have also contributed to the process of ecological degradation and resulted in substantial changes to local subsistence practices. For example, Fox (2000:24) reports that during the latter part of the Portuguese colonial period, the Government initiated a series of agricultural extension programs in an attempt to 'induce a shift of population' to the least-populated southern coast of Timor. While the ecological and population density variability found across Timor-Leste was perhaps not an intended consequence of such social displacements, colonial resettlement schemes have, in part, contributed to the situation wherein the Lautem district in the far east of the country has one of the lowest population densities and some of the more extensive forested and coastal resources of all the regions in TimorLeste. In the period of Indonesian occupation, as Soares (2001:20) points out, napalm bombing and forced resettlement practices by the military 'saw a mass destruction of the environment' and resulted in widespread famine. Dunn (1983:338) also comments upon the 'rapacious exploitation' of sandalwood and other forest-based resources, which the Timorese traditionally depended on for their livelihood, during this period. Speaking of livelihoods, both Soares and Fox report that traditional identities, constructed around particular modes of livelihood, have been severely eroded over the past 25 years as a result of population movements and a greater emphasis upon rice and commercial crops, such as coffee (Fox 2000:25; Soares 2001:19-20). Indeed, Shepard Forman (1981:87) goes so far as to conclude that for the Makassae of Timor-Leste, with the loss of their means of livelihood during the period of occupation, 'the cycle of production and exchange which reproduces life has been broken'.

While the Sustainable Development conference delegates emphasised the rampant 'destruction' (Anderson and Deutsch 2001:20) of the environment resulting from this history of colonisation and forced occupation, it is a history that also alerts us to the adaptive nature of Timorese subsistence practices. For many so-called 'farming' communities throughout Timor-Leste, critical to their survival throughout this turbulent history was a reliance upon a variety of resources gained from hunting-and-gathering activities in local forests and woodlands, waterways and inshore marine areas.

The anthropological and economic literature on East Timorese societies is somewhat silent about these practices, often depicting shifting cultivation as the sole means of subsistence or as the predominant 'life paradigm' (Forman 1981:96). Certainly, in some areas of Timor-Leste today - for example, in central Ainaro and in heavily populated areas of Bobonaro, where deforestation and extensive cultivation have led to an almost complete reliance upon swidden or seasonal dryland agriculture, and the concomitant attenuation of non- 
agricultural subsistence practices - this is increasingly the day-to-day reality (A. McWilliam, Personal communication). While historically local people in these areas might have pursued more diverse subsistence practices, population pressure and the expansion of the amount of land under intensive cultivation have effectively served to narrow local livelihood options.

As Fox (1977:17) points out, however, in characterising Indonesian ecological systems as based upon wet rice cultivation or swidden agriculture, other 'important ecological systems in the outer islands' are neglected. Some idea of the existence of these other systems is apparent in the written record where, as the pages of history indicate, an agricultural-centric model of Timorese life has not always predominated. For example, on the voyage of the Dutch brig-of-war Dourga to Portuguese Timor in 1825, Kolff, the commander of the expedition, commented upon the 'neglect' of agriculture in the districts around Dili. Kolff writes that while the land was 'highly fertile', it appeared to him that the Portuguese were too 'indolent' to turn their attention to agriculture, while the 'natives' were too engaged in the local, highly profitable slave trade to bother with such pursuits (Kolff 1840:38). From Kolff's account, it is clear that Portuguese Government officials derived a considerable portion of their income from the slave trade, and also from the commerce in beeswax and sandalwood, which local people were 'forced to deliver up at a small, and almost minimal price' $^{\prime}$ (p. 35). ${ }^{2}$

On his visit to East Timor in 1861, Alfred Russell Wallace also reports upon this latter commerce, stating that 'almost the only exports of Timor are sandalwood and bees'-wax' (1872:199). Identifying beeswax as the more 'valuable' and 'important' of these two products, Wallace provides a detailed and vivid description of native men harvesting honey and wax from a wild bee colony in the forests above Dili. ${ }^{3}$ Sandalwood and wax are also mentioned as two of the products of Timor recorded by Pigafetta in 1522, while one of the first European references to Timorese sandalwood, dating from 1518, identifies 'sanders-wood, honey, wax, slaves and also a certain amount of silver' (Dames 1921:195-6) as traded items from the island. ${ }^{4}$ Some 300 years later, George Grey, summarising the state of trade in the Indian archipelago, reports that the produce of Timor consists of 'goats, pigs, poultry, maize, paddy [sic], yams, plaintains, fruit, sandal-wood, bees-wax and tortoiseshell’ (Grey 1841: vol. 1, p. 282).

\footnotetext{
2 Some 150 years later, a similar situation existed in Indonesian-occupied East Timor with respect to the small, but profitable coffee industry. As Dunn reports, the income from this industry 'became an important source of private gain to a group of senior [Indonesian] military officers' (1983:337).

3 Gunn (1999:115) reports that in the early nineteenth century, more than 20000 piculs (a local measure of weight, equivalent to $137 \mathrm{lb}$, according to Echols and Shadily [1990:428]) of beeswax was exported annually from Portuguese ports in Timor.

4 Other products recorded by Pigafetta are 'ginger, buffaloes, pigs, goats, fowls, rice, bananas, sugarcane, organs, lemons....almonds, beans and gold' (cited in Glover 1986:11).
} 
In the twentieth century, Ian Glover makes mention of non-agricultural subsistence practices in East Timor, and discusses how caves are used 'as temporary camps for parties out hunting in the dry season' (1986:206). According to Glover (1986:206-7), 'cave occupation reflected mostly the hunting and collecting aspects of life', which he believes did not reflect the 'total Timorese way of life'. In contrast, the Portuguese archaeologist Antonio de Almeida (1957:241) found that hunting and fishing by the inhabitants of East Timor contributed to a 'great part of their maintenance'. Almeida discusses at length communal hunting of deer, boar and buffaloes, and reports upon the local procurement of shrimps, eels, fish, lobsters, oysters, crabs, turtles and tuna from the rivers, fresh and saltwater lagoons and the seas of East Timor.

Like Almeida, McWilliam (2001:89) observes that so-called swidden agriculturalists 'continue to draw heavily on the existing diminishing forest resources'. He also suggests, however, that the exploitation of forest-based resources for firewood, building materials and natural medicines and for 'supplementary hunting' is contributing to the 'deteriorating condition of forest ecology' (2001:90). Other accounts - notably by members of the Government's forestry unit-give the impression that these activities are relatively recent, and that local people are forced to exploit forest resources as a result of unemployment and high prices for staple items (Martins 2001:32), producing even further environmental degradation.

The anthropologist Claudine Friedberg (1989) is one of the few writers to explore the relationship between the activities that take place in these forested areas and agricultural practices. As Friedberg discusses, among the non-Austronesianspeaking Bunaq, whose traditional lands fall around the southern border area, agriculture is dependent upon the ritual hunting of wild pigs and the gathering of forest fruits and medicinal plants. Critical to local ritual is the exchange of these non-cultivated items with the ancestors of the 'upperworld' and between members of the village community prior to the sowing and harvesting of the rice and maize crops. Friedberg's discussion points to a more integrated view of subsistence, where hunting and gathering and agricultural cultivation are interdependent and mutually linked to the reproduction of the village's social and territorial integrity. Critical to this view are the interpenetration of economic and cultural activities, and the role of such productive actions in the creation of cultural values and social identities.

In this sense, Bunaq farming rituals represent the ongoing work required in the 'production of locality' and a distinctive subjectivity or 'sense of place' (see Appadurai 1996). As Appadurai points out, place is produced through the intersection of social relations, expressions of identity and the practice of culture. As the Bunaq example illustrates, the production of locality thus 
involves various relationships to land and landed practices, not simply those designated as 'swidden agriculture' or characterised as 'hunting and gathering' in the dualistic framework of the 'subsistence economy' discourse.

Acknowledging the problem with isolating and packaging specific practices as such and thus disregarding the social and cultural context in which knowledge is generated and put to practical use, in this chapter, I propose to adopt a more holistic view of subsistence than previously reported. For example, in a recent paper focused on the Fataluku-speaking ${ }^{5}$ districts of Com and Méhara, Pannell and O'Connor (2005:196-7) briefly reported on inshore reef fishing and littoralzone foraging, and observed that 'various species of game birds, together with deer, wild pigs, monkeys, civet cat and cuscus are regularly hunted by local people'. Also commenting on the subsistence practices of Fataluku people in the Lautem district, McWilliam (2006:2) reports that hunting in the forests and coastal margins is regularly undertaken and he states that the local population relies on a 'wide variety of forest products'. While these references to Fataluku hunting-and-gathering practices constitute notable exceptions in the overall literature, there is a strong suggestion that these activities are merely secondary or supplementary to agricultural production.

Once again focusing upon the Fataluku-speaking district of Lautem, and more specifically the posto or 'subdistrict' of Tutuala, I aim to make more visible those livelihood practices eclipsed by the prevailing and materially visible picture of cleared fields and unproductive farmers. ${ }^{6}$ In this chapter, I attempt to explore the more varied and dynamic nature of local patterns of 'making a living'. ${ }^{7}$ An integral element in these patterns of productive action is the shifting and recycled nature of the Fatluku landscape, as a back-and-forth movement between garden and forest. As I discuss, this recursive movement is not confined to so-called 'subsistence practices'; it is also a key structuring leitmotif in local engagements

5 Throughout this chapter, I adopt the orthography identified by the Fataluku Language Project, a community-based project conducted under the auspices of the Instituto Nacional de Linguística at the Universidade Nacional Timor Lorosa'e. This project is sponsored by the Endangered Languages Program of the Netherlands Organisation for Scientific Research (NWO) and involves professional linguists from the University of Leiden. The orthography developed by this project differs slightly from the one used by researchers at the Language Documentation Center at the University of Hawai'i at Manoa for the Fataluku language.

6 Michael Dove (1983) provides an insightful critique of the view of shifting cultivation as a delinquent pattern of resource extraction and its practitioners as wasteful and unproductive.

7 Tutuala is one of five posto or subdistricts in the district of Lautem (the other posto are Iliomar, Lautem, Lospalos and Luro). The district of Lautem has a population of some 57453 residents (as of 2004), and a population density of 33.8 inhabitants per sq km, making it one of the least-populated areas in Timor-Leste. Previously, the district capital was Lautem, but for some time now Lospalos has performed this function. Each subdistrict is divided into a number of villages (suco), which in turn might contain several hamlets (aldéia). The posto of Tutuala includes the suco of Tutuala, Mehara and Maupitine. The administrative head of the subdistrict, the chefe do posto, resides in Tutuala. In the nested structure of local government in Timor-Leste, each suco and aldéia also has an administrative head (the chefo do suco and chefe do aldéia, respectively). The suco of Tutuala comprises the hamlets (aldéia) of Pitileti, Ioro, Vero and Cailoro. 
with a series of state regimes (that is, the Portuguese and Indonesian colonial administrations), and in the stories Fataluku people tell of how they survived these encounters.

Like the Bunaq context, in Tutuala, these projects of place making are mediated by a quotidian engagement with the non-human beings endemic to this part of the Timorese landscape. As Friedberg's discussion indicates, the 'life-force' emanating from these beings traverses social groups and 'cuts across village boundaries', blurring any sense of local places and livelihood practices as immutable, bounded or homogenous. These references to a sentient landscape alert us to the limitations of a strictly subsistence-focused discourse.

Unlike the Bunaq example, however, I also discuss elements of Fataluku productive action in the context of some of the political fields in which they reside and struggle. In this respect, I focus upon the strategic role of Fataluku hunting and gathering during the period of Indonesian occupation and the significance accorded these forms of indigenous labour within certain contested spaces by the newly formed Government of Timor-Leste. As I hope to demonstrate, to paraphrase Elizabeth Povinelli, Fataluku people's productive encounters with the landscape provide them with a way of 'attending to and ensuring the physical, mythical, and emotional production of the environment, the human body, and the social group in the midst of ecological adversity and sometimes horrendous historical upheavals' (Povinelli 1993:30).

As I discuss, the diverse nature of Fataluku economic practices - entailing and blending agricultural and hunter-gatherer type activities-provides the kind of subsistence flexibility that enables local people to deal with chronic environmental uncertainty. In this respect, Fataluku livelihood practices perhaps have more in common with the lontar economies of outer arc islands to the west of Timor than they do with swidden systems on the island itself (see Fox 1977). ${ }^{8}$

The diverse and flexible nature of the Fataluku system also provides local people with the means to cope with radical political change. This flexibility certainly facilitated local, forest-based resistance to the Indonesian occupation in the period 1975-99, particularly given the Indonesian military's 'search-anddestroy' missions, mounted with the 'deliberate aim' of destroying local food crops and domestic animals (Dunn 1983:307). ${ }^{9}$ While local Falintil members relied upon their extensive knowledge of forest foods and medicines and their

8 As Fox discusses in his ethnography Harvest of the Palm (1977), the lontar-focused economies of Roti and Savu are 'marvelously stable and adaptive', in contrast with the 'slash-and-burn' agricultural economies found on the neighbouring islands of Timor and Sumba, which have 'led to steady ecological deterioration'. 9 Dunn (1983:336) reports that the water buffalo population of East Timor declined from 150000 in the mid-1970s to less than 25000 by 1981. 
expert hunting skills to survive and defeat the numerically superior Indonesian forces, in post-independence Timor-Leste (see Collins et al. 2007; Pannell and O'Connor 2005), as I discuss in the concluding sections of this chapter, these once-regarded heroic elements of Fataluku subsistence are now, paradoxically, under threat from the nation-building activities of one of the world's newest democracies.

\section{Alahu and Tahi}

The agrarian image of Timorese society is reinforced by the overall impression presented in the literature that Timor-Leste comprises a 'harsh', droughtridden landscape that has been cleared, cultivated and, ultimately, degraded by the actions of humans. ${ }^{10}$ Yet, throughout this same countryside can be found extensive tracts of primary rainforest and montane cloud forest, as well as swathes of secondary vegetative growth, watered by the 'double monsoon' experienced in Timor-Leste and on the neighbouring islands of eastern Indonesia (McWilliam 2003:309, 311). Reported upon by several commentators from as early as 1885 (see Forbes 1989 [1885]:454), many of these forest 'groves' are said to persist into the present because of the 'lulic'11 or 'sacred' status accorded them by the local custodial community (see also Glover 1986:21; King 1963:14850; McWilliam 2001:90, 2003:311; Metzner 1977:98; Ormeling 1956:85; Therik 2000; Traube 1980:295). As the naturalist Henry Forbes discovered-much to his disappointment - a range of ritual prohibitions exists regarding access to and use of forested tracts designated as lulic.

'Sacred' or tei forests also exist throughout the district of Lautem, which is a fertile and well-watered region, supporting large expanses of primary and secondary-growth forest. In the Fataluku language, there are a number of terms used to describe forested spaces that do not specifically conform to the scientific classification of forest as 'primary', 'secondary', and so on. ${ }^{12}$ The general term for forest is alahu. Hoto is a term that is also used to describe forest generally, but it also, more specifically, refers to 'wilderness', while forests containing wild

\footnotetext{
10 To some extent, this is a perspective based upon the more populous north coast and its hinterlands, which, in contrast with the extended periods of rainfall experienced in the mountain areas and on the southern coast, is visited by 'long stretches of seasonal drought' (McWilliam 2003:309).

11 Lulic is a Tetun word and equivalent terms exist in the other languages spoken in Timor-Leste (see McWilliam 2001).

12 In a similar manner, Friedberg (1979:85) observes that among the Bunaq, plants are classified according to a 'complex web of resemblances and affinities', rather than according to a 'tree-like system of hierarchical categories', as represented by the Linnaean system of taxonomy.
} 
animals are known as caikeri. Forest containing large, closed-canopy trees is called irinu $^{13}$ - a reference to the mature or 'old' (irine) status of these trees, while young, regrowing brush is called totoku.

Throughout these forests grow economically important stands of bamboo (liru-four species are identified by informants), sugar palm (tua ma'arau), tamarind (kailemu) and timber (ete). The forest is also home to various species of game birds (aca hoto), together with deer (vaka hoto), wild pigs (pai hoto), monkeys (lua), bats (maca), civet cat (pusa hoto) and cuscus (acuru), which are regularly hunted by local people. Fataluku men collect, in addition to these faunal and floral resources, beeswax ${ }^{14}$ (vani capu) and honey (vani ira), the nests of swallows (lelilawu), building materials, root dyes, and medicinal (eteasa) ${ }^{15}$ and poisonous plants from the forest, and, in more recent times, graze buffalo (arapou) throughout this area.

Throughout the forest important subsistence resources such as lontar palms (kakalu), bamboo stands and coconut palms, as well as former garden sites (pala), are marked by ritual signs called lupurasa. Lupurasa signs, such as young coconuts and monkey skulls, warn others against using the marked object. Ignoring this warning is said to result in injury, sickness and sometimes death. According to informants, ratu groups possess their own distinctive lupurasa signs.

In the Tutuala area, the forested landscape extends to the coast, and embraces both the 'male sea' (tahi calu) in the south (the Timor Sea) and the 'female sea' (tahi tupuru) in the north (the Strait of Wetar). Fataluku men and women regularly walk down the series of uplifted limestone terraces to fish for both demersal and pelagic species, hunt for turtles, octopus and crustaceans, and collect various species of shellfish in the intertidal zone and on the fringing reefs. In late February and March, the Fataluku-speaking communities in the Tutuala area and beyond collectively participate in the ceremonial harvesting of sea worms (meci). While the reef-based subsistence activities of Tutuala residents were photographed by members of the Siboga Expedition more than 100 years ago (in January 1900) (Weber 1902), recent archaeological evidence, however, points to a local reliance upon marine resources spanning a period of more than 30000 years (S. O'Connor, Personal communication; see also O'Connor and Veth 2005).

13 In his word list from Oirata, a 'Timorese Settlement on Kisar', Josselin de Jong (1937:24) records irim(i) as the word for 'forest, bush' and also the term for 'old'. Iririmi is given as the term for 'brushwood'.

14 Earl (1853:182-3) reports that in the 1850s 'quasi-Papuan tribes' from 'Kapalla Tanah' or the far eastern point of the island of Timor-in other words, Fataluku speakers - traded beeswax with traders from the 'Serwatty Islands' (the Southwestern Islands north-east of Timor, including Leti, Moa and Lakor).

15 A recent ethno-botanical study of medicinal and poisonous plants used by the East Timorese resistance, undertaken in the proposed Nino Conis Santana National Park in the Lautem district of Timor-Leste, identified more than 40 medicinal and poisonous plants (see Collins et al. 2007). 
Hunting (haware) and gathering in the coastal zone are facilitated by the use of wooden canoes and boats (loiasu), ${ }^{16}$ bamboo spears (api coro) and handlines, while dogs, blowpipes (tutufa), airguns, metal spears (coro) and twine traps (hilu) are used to hunt deer, monkeys and pigs in the forest.

In the forest and along the coast, Fataluku hunter-gatherers obtain water from a range of sources, including permanent springs (ira ina) emerging at an altitude of about $300 \mathrm{~m}$ in the uplifted limestone terraces; a number of spring-fed sources along the coast accessible only at low tide; seasonal rockholes (piaru) (often protected with a rock lid); ephemeral creeks and rivers (veru); temporary rainfilled depressions (luri); drip seepage (cupucupu) and drip-fed pools in caves.

Local people know the forested and coastal environment of the Tutuala region in terms of a series of named locales. Names for an identified area often derive from that of a former settlement located within the area. Conversely, some former, pre-Portuguese settlements, such as Tutuhala, take their name from a nearby mythological site, which also defines the identity of the general locale. In some cases, locality names derive from specific environmental features. Throughout the forests of the Tutuala region, locales might also be known by the name of an individual tei site.

Tei are seen as malevolent and motivated forces, which occupy pre-existing places within the local landscape. They are said to 'guard' an area and the people of the clan group or ratu associated with it. Ratu members perform rituals at the tei to ensure prosperity, fertility and good health. While tei are often described as 'wild' or hoto, and many are said to be located throughout the forest, tei-based rituals involve 'feeding' these non-human beings with domesticated foodstuffs, such as 'rice, eggs, pig meat and palm spirit' (Pannell 2006:208). To 'cool' the tei, however, it is necessary to 'feed' (fane) it uncooked (u'ureke) food. Ceremonies conducted at tei sites are not just for humans, but also for the environment as a whole. As such, the cultural beliefs and social practices associated with tei have wider ecological effects. As this suggests, for Fataluku people, nature and culture do not exist as separate realms of meaning or practice. The landscape of the Tutuala region bears testimony to the indivisible relationship that exists between the physical environment and local traditions. The existence of extensive tracts of forested land as an integral part of this landscape is not just, however, a function of the protection offered through the local value placed upon 'sacred groves'. As I discuss in this chapter, the concept of lulic, or tei in Fataluku, is inextricably linked to other cultural conventions, social relations and place-making activities.

16 Loi is the term for 'boat' in the Austronesian language spoken on the island of Leti (van Engelenhoven 1997:14). Josselin de Jong (1937:270) gives 'rusunu' as the term for a 'native boat' or 'canoe' in the Fataluku language spoken in the village of Oirata on the island of Kisar. As McWilliam (2007:6) points out, there is considerable lexical borrowing from Austronesian languages in contemporary Fataluku speech. 
As discussed in this section, in the Tutuala area, forests also persist because social identities are forged in these spaces and 'they take on the complexity of associations with the forest landscape as a fabric of diverse social and natural resources' (Tsing 1993:62). Thus, in post-independence Timor-Leste, despite a history of social dislocation, violent political ruptures and ongoing economic instability, the forests of Tutuala continue to support a range of traditional livelihood practices. Moreover, these spaces provide a tangible environment for the situated expression of Fataluku values about locality and local subjects. In the recent past, these values were also realised in the context of labile, forestbased communities, known as lata.

\section{Lata}

The popular characterisation of Timorese society as agrarian conveys a sense of stable human settlement, with social identities forged in domesticated villages. In the subdistrict of Tutuala, however, permanent village enclaves date mostly from the later period of Portuguese rule - post 1945 - intensified during the first years of the Indonesian occupation, and are linked to the efforts of the governing authorities to practically control the populace through their resettlement on the edges of roads or along the coast. It is important to realise here that until World War II (and for some years afterwards) the occupation of the inhabitants of the Tutuala area was still focused upon foundation or ancestral centres located deep within the forest.

In contrast with the idea of fixed agrarian communities - heavily promoted and forcibly implemented during the Indonesian period (see Dunn 1983:336) - the oral histories of Tutuala-based ratu or 'clan groups' are stories about mobility, recalling as they do the establishment and abandonment of occupation sites by specific ratu as they moved throughout the forested upland areas of Tutuala. These sites include former walled and current open settlements (lata), caves (veraka) occupied by ancestral figures, and rock shelters and caves used in prehistory and during the Japanese and Indonesian occupations of the island. Several former settlements are also found on Jaco Island (Totina). Lata and other site types provided the ritual and occupation focus for dispersed kin groups exploiting the surrounding forests and tending nearby swidden gardens (pala). Former walled settlements also contain circumscribed ceremonial spaces called sepu and ancestral graves (calu lutur or narunu), while both settlements and the caves occupied by Fataluku ancestors contain guardian tei sites (lata toton). As 
additional elements to the stone walls that apparently served to fortify lata, several species of cacti (latu) - each possessing different repellent properties were planted along and around the perimeter enclosure. ${ }^{17}$

A number of these stone-fortified settlements in the Tutuala area have been test pitted and/or material has been obtained from within the perimeter of the stone walls for dating. Results of radiocarbon dating on marine shell and charcoal and optically stimulated luminescence (OSL) dating of pottery from the test-pitted sites suggest that the fortified structures began to be constructed about 1300 AD. ${ }^{18}$ They appear to have been erected and used into the historical period, and some were still in use until the middle of the twentieth century (Lape 2006). As McWilliam (2003:311) points out, 'inter-domain feuding and warfare... encouraged widespread settlement of small populations in strategic defensive locations on barricaded hilltops'. While these ancestral settlement sites are no longer permanently occupied, ratu members regularly perform rituals and ceremonies at the tei and gravesites located within these walled settlements.

These former, named settlements are often described by present-day Fataluku speakers as lata irata - not only a reference to the 'overgrown' (irinu) ${ }^{19}$ status of these previous occupation sites, but also a statement about the integrated nature of forests and human settlement in this part of Timor-Leste. Like the situation described by Valeri (2000:15) for the Huaulu in Seram, the forest here also claims 'back the spaces that humans have managed, at one point, to cut out of it'. In this sense, the forests of the Tutuala district are imbued with a history of human movement, occupation and use. The history of these forests is not just a story about the journeys taken and settlements occupied by ratu groups, but it is also a story about gardens and gardening.

17 On a visit to the former settlement of Locami, informants identified five different species of cacti (latu) latu irinu, latu uku, latu pokala, latu lépenu and latu sériku - growing along the perimeter walls of the lata. 18 While Lape links the emergence of fortified settlements in East Timor with a period of rapid climate change and inter-group conflict, it has also been well established that slavery flourished in eastern Indonesia following the introduction of Islam in the East Indies in the thirteenth century (Grant 1964:9). As Andaya (1991:83) observes, the demand for slaves from the east increased when the Dutch East India Company (Vereenigde Oost-Indische Compagnie: VOC) 'forbid the use of slaves from Butung, the Malay areas, Makassar, Bali and Java'. In a commentary on 'Papuans' in the Indian archipelago, Earl (1853:182) reports on the 'quasiPapuan tribes' (I take this to be Fataluku speakers) of south-eastern Timor. He observes that these people are wary of strangers and have good reason to be so because the 'great slave mart of the Bughis and Macassar traders, Kapalla Tanah, or the Land's-end, is in their immediate neighbourhood' (Earl 1853:182). 'Kapalla Tanah' (Kepala Tanah or 'Head of the Land') is the name that appears on maps from this period for the easternmost point on the island of Timor (Weber 1902), which is occupied by Fataluku speakers today. As Earl's account indicates, slavery was certainly a real fact of life in the mid-1800s for Fataluku people.

19 The term irinu is also used to describe dense stands of primary rainforest. 


\section{Pala}

In a recent article on Fataluku forest tenure, Andrew McWilliam (2006:3) identifies Fataluku people as 'a predominantly agrarian society', and states that they have 'for centuries pursued systems of...dry land swidden agriculture combined with irrigated rice production'. This said, Fataluku people from the Tutuala area associate wet rice production with the agricultural extension programs introduced by the Portuguese Government in the 1960s and the efforts of the Indonesian authorities, post 1977, to promote a more familiar idea of what constituted landed productivity and agricultural stability (see Fox 2000; Tsing 1993). ${ }^{20}$

The short history of irrigated rice production in this area stands in contrast with the relative antiquity of shifting cultivation. ${ }^{21}$ For Fataluku people, this history (rata) of shifting cultivation is marked by the stone walls (lutur) of former gardens that crisscross the forest landscape and the particular history of plant succession associated with these areas. In a similar manner to the way in which former settlements - particularly those regarded as the earliest occupation sites - are associated with gigantic forest tress, especially strangler figs (hama), the memory of former gardens (pala cenu) is also linked to particular plants and plant communities. Long grass and bushy growth (mainly, Imperata cylindrical, Chromolaena odorata and Lantana camara L.), remnant fruit trees and lontar palms (tua ma'arau) often mark more recently abandoned gardens, while sites gardened in grandparental times have become forest again in the eyes of Fataluku people. As this suggests, forests in the Tutuala area are truly anthropogenic spaces, where old gardens become newly forested areas and mature forests in turn are potential garden sites. The memory of this transformation is articulated as a history of human use and social relationships, as people walk through the forest remembering the gardens of their kin and neighbours, and the stories associated with them.

Most people maintain at least one garden for several years, which is planted with a wide range of edible and non-food plants, including corn (cele), cassava (ete lusu), pumpkin (tau), various kinds of yams and beans, bananas, papaya, tobacco, and an array of herbs and spices. The emphasis on phased planting and multiple cropping in Fataluku gardens makes them similar to Hanunóo swidden plots (see Geertz 1963:19). As Clifford Geertz (1963:19) observes, these subsistence practices 'give an excellent picture of the degree to which this [type of] agriculture apes the generalized diversity of the jungle which it temporarily replaces'.

20 In a similar manner, Friedberg (1977:149) notes that among the Bunaq, irrigated rice paddy is identified as 'an innovation of the Japanese who forced the Timorese to use this method during the last war'.

21 Earl (1853:182) reports that in the 1850s 'quasi-Papuan tribes' from 'Kapalla Tanah' or the far eastern point of the island of Timor - in other words, Fataluku speakers - 'grow maize and yams'. 
In June and July, when the nights turn cold, ${ }^{22}$ Fataluku people start to prepare their swidden gardens for planting later in the year. For existing gardens, preparation largely entails weeding, while for new gardens, extensive tree cutting and undergrowth clearing take place, enabling the burning and fencing of the garden, which take place about October or November. The period from July to November is called mokurahunu and is defined by the prevailing southerly winds and the eventual onset of the dry season. About November, the winds shift to the north, marking the commencement of the period known as aianhisinu - associated with the first soaking rains and the commencement of the phased planting cycle. This period continues through to April when temuru, or the wet season proper, as far as local people are concerned, begins.

Given the history of swidden cultivation in the area, and the long cycles of forest-plot rotation, most gardens in Tutuala are developed out of secondaryforest land that has been fallow for a number of years. In the Tutuala area, demarcated tracts of land are readily identified in terms of their ancestral ratubased association. Individuals do not, however, confine their gardening activities to the lands linked to their particular ratu group. In this sense, gardening reflects a person's position in a diverse network of consanguineous and affinal kinship ties, which cut across clan group membership and the boundaries of ratu-identified lands. The mosaic landscape of gardens that emerges each year in the Tutuala region not only conveys a sense of current social connections, it also links present gardeners to the actions of previous users, and to the powerful beings that control fertility in this area.

The creation of a new garden or the opening of a fallowed plot entails making offerings (siri ho catu fane) to the tei being 'guarding' that particular area. When ritually fed, this being is said to ensure the fertility of the land and protect those involved in associated gardening activities. Gardening is an inherently social undertaking and the opening of a new garden and the subsequent harvesting of garden produce, particularly corn, involve the collective assistance (lehen pala fai) of other ratu members and collateral kindred. Like the situation described by Friedberg for the Bunaq, in Tutuala, the rituals associated with the cultivation and harvesting of gardens are accompanied by hunting and gathering and the shared consumption of mainly forest-based products by the extended kin groups formed on these occasions. The dual nature of 'harvesting' here, from forest and garden, together with the shifting and recycled nature of the landscape, as a back-and-forth movement between garden and forest, erode the neatly drawn semantic boundaries between agrarian societies and huntergatherers - a typological erosion dramatically illustrated by local occupation and use patterns during the period of armed resistance to the Indonesian occupation of East Timor. 


\section{A Geography which Struggles II: 'Running to the forest, hiding in the mountains'}

People interviewed in the Lautem district spoke of everyday survival and the years of armed resistance to the Indonesian forces as a constant movement between roadside village sites and the nearby forest or mountains. As Pannell and $\mathrm{O}^{\prime}$ Connor (2005) report, at various times during the Indonesian occupation, entire villages in the Lautem district would flee to the familiar surroundings of the forest or to the mountains and take refuge in caves. For example, in 1975, in the suco of Méhara, part of posto Tutuala, most of the population fled to the forest and lived in a series of caves until 1977, when they returned to live by the side of the road again. A similar exodus occurred in July 1999, at the height of the militia violence. Only after the referendum did most of the villagers emerge from the forest. Even then, some chose to remain in the forest. After the Indonesian forces left Méhara, at least two families continued to live in the cave known as Piriluturu, near the village of Loikero. All of the hamlets within Méhara were looted and public buildings, such as the school, were destroyed by the Indonesian armed forces (Tentara Nasional Indonesia or TNI ${ }^{23}$ and the roving militia gangs during the lead-up to the referendum. A number of the local residents were tortured and some were also killed at this time. The violence and terror, however, were not confined to this period. For local people, the entire period of the Indonesian occupation is associated with such events and emotions, mediated by their experience of 'running to the forest' and 'hiding in the mountains'. ${ }^{24}$

In Indonesian nationalist discourse, hutan ('forest') and gunung ('mountains') are part of a social landscape signifying political marginality, cultural differences and economic imbalances. As Tsing (1993) points out, in this discourse, rainforest shifting cultivators and the inhabitants of upland areas are generally regarded as socially 'primitive' and economically 'backward'. For policymakers and Indonesian civil servants alike, these are people and places that are also associated with moral uncertainty and physical danger, where the boundaries between the natural and supernatural worlds are blurred. In contrast with the pan-Indonesian coastal culture - characterised by adherence to Islam - these interior and upland areas are regarded as being inhabited by headhunters, animists and all manner of non-human beings. Continuing the colonial tradition established by the Dutch, state development programs in Indonesia involving these allegedly 'isolated' groups (BI: suku terasing) are largely presented as

23 For most of the period that Indonesian forces occupied East Timor, the Army was known by the acronym ABRI (Angkatan Bersenjata Republic Indonesia). The Indonesian armed forces were renamed Tentara Nasional Indonesia (TNI) towards the end of the occupation.

24 Articulated to the researcher as 'lari ke hutan, sembunyi di gunung'. 
civilising missions aimed at promoting compliant, modern citizens. Often this objective is affected through the forced resettlement of forest and upland communities to more manageable terrains - to coastal lowlands or closer to regional administrative centres.

As Kenneth George (1996) observes for the upland Mappurondo group in Sulawesi, these distinctions between upland and lowland, the interior and the coast, also feature in local cosmographies, though the significance attached to these classifications is often an inversion of the official discourse. This is a point also made by Valerio Valeri in his discussion of the rainforest-dwelling Huaulu people of the mountain interior of Seram. For the Huaulu, the opposition between the superior upland groups and the weaker coastal peoples is not only underscored by Huaulu myths and perceived behavioural differences, but also pivots on a contrast between 'indigenousness and immigrant status' (Valeri 2000:22) - with the latter status less valued than the former. In Huaulu society, a further opposition exists between the forest and the village. As Valeri points out, this relationship between the village and the forest is a complex, 'fearsome symmetry': 'Humans are not only outside the forest and against it, but also of it. Like all creatures, they follow its law: hunting and being hunted, killing and being killed' (2000:16).

For the Huaulu, however, who are subject to this law of balance and retribution, 'there are ways to regulate, displace, or even repress its operation' (Valeri 2000:16).

And so it is the case for the people of the Tutuala area. The forest and the mountains are important sources of non-domesticated food and other resources traditionally utilised by local people. They are also the sources of ancestral and non-human power. These are spaces inhabited by people's ancestors and other named beings. Like the Huaulu, the people of this region recognise the need to engage with and, where possible, propitiate these beings. Their ongoing occupation of the forest is mediated by the maintenance of these relationships. Perhaps, at no time was this more important than during the Indonesian occupation, when local resistance entailed waging a guerilla war in the forests and upland areas of the region.

Like the situation in other villages throughout Timor-Leste, in the Lautem district, many of the able-bodied men became Falintil (an acronym for the Armed Forces for the National Liberation of East Timor ${ }^{25}$ resistance fighters. They

25 In July 2005, I was part of an ANU-based team that excavated a rock shelter in the Tutuala area known as Jerimalai. Analysis of the excavated materials is ongoing but the radiometric dating of the lower levels has demonstrated that it is the oldest occupation site in island South-East Asia, east of the Sunda Shelf. The basal level of Test Pit A is dated at $38255+/-596$ (Wk-17831). The basal date for Test Pit B is $37267+/-453$ BP (Wk-17833) (S. O'Connor, Personal communication). 
spent years living in caves throughout the forests, often fighting the Indonesian forces with homemade rifles and bullets made from sharpened stones. Falintil's occupation of the forests in the Lautem district varied in duration. At times, caves were used for only a couple of hours at a time - for example, while the men cooked the game they had caught in the forest or slept briefly before moving on to the next cave site. At other times, caves were occupied for much longer periods, becoming temporary headquarters for Falintil's operations in the district. Timor-Leste President and former leader of the Falintil guerilla force, Xanana Gusmão, was among the freedom fighters who sought refuge in the many caves dotted throughout the suco of Méhara.

Talking to ex-Falintil members, it became apparent that creating a sense of disorientation and displacement within the forest environment was an essential element in their strategy of subverting the Indonesian forces. For these men and women, the covert and shifting nature of the guerilla war waged between local people and Indonesian forces was one that they were well equipped to participate in with their intimate knowledge of the local landscape. Contrary to the attempts of the Indonesian Government to homogenise people's experience of space in terms of a range of standardised administrative areas and boundaries, it is perhaps local people's understanding of their environment as a landscape of micro-differentiations that enabled them to disperse and ultimately dispense with the numerically and technologically superior occupying forces.

As the previous discussion indicates, an important element in the development and success of the East Timorese independence movement is its material and political recolonisation of the spaces demonised by the Indonesian authorities. Moreover, the command of the 'forests' and the 'mountains' by Falintil guerillas signalled a reclamation of local history and culture, discursively focused as it is upon caves, ancestral centres and other places within this geography. The emplacement of Timor-Leste's recent history of violence and resistance in this landscape of forests and mountains is also an important element in an emerging national identity. In the Lautem district, people's reoccupation of the forest during the Indonesian period is often invoked to illustrate the new relationship between citizenry and state-local villagers and the national president alike shared the experience of being forest-dwellers. As this suggests, forests and mountains feature in a national territorial strategy to memorialise and eulogise recent events and identities. In this situation, individual biography and collective history are seen to coalesce at various spatial intersections, to the point where forests and mountains represent monumental spaces in the unfolding terrain of the new nation-state (see Pannell and O'Connor 2005). 


\section{A Geography which Struggles III: Concluding remarks}

In many respects, the livelihood practices of Fataluku people in the Tutuala area have more in common with the Meratus Dayaks of Kalimantan (Tsing 1993) and the Hualulu of Seram (Valeri 2000), who are more readily recognised in the literature as 'forest-dwellers' or 'hunter-gatherers', than as 'agrarian societies'. While much has been written about the 'ecological Eden' conjured up by overly romanticised, and ultimately primitivising, images of 'indigenous' peoples and lifestyles (Ellen et al. 2000), as my comments in the previous section indicate, we are also familiar with the political and rhetorical effects of a group or a people being labelled as 'traditional hunter-gatherers' or as a 'forest-dwelling community', as opposed to an agrarian society. The designation of a community as 'farmers' or their livelihood as 'agrarian' effectively erases their overlapping and multiple social interests and ancestral connections to forests and other noncultivated spaces. As Anna Lowenhaupt Tsing (1993:xi) observes, in the context of 'expanding capitalisms' and 'contested cultural politics', such designations contribute to, and are part of, the construction of local marginality. In the new era of Timor-Leste's nation building, heralded by independence in 2002, Fataluku people are in real danger of being excluded from the very landscape that they and their ancestors have shaped and transformed over the course of thousands of years.

As previously indicated, the eastern region of the Lautem district contains one of the largest continuous tracts of lowland tropical and monsoon forest on the island of Timor. This forested region covers an area of some $300 \mathrm{sq} \mathrm{km}$ and features the steep-sided and densely vegetated Paichao Range along the southern coast, near the village of Loré. During the period of Indonesian occupation, 1975-99, a large proportion of this area was classified as a nature conservation reserve (kawasan suaka alam), while under the UN Transitional Administration in East Timor (UNTAET), the area was declared a 'protected wild area' (see McWilliam 2006). It is this area that the Directorate of Forestry (Government of Timor-Leste) seeks to protect as the country's first national park: the Nino Conis Santana National Park.

From a conservation perspective, the area proposed for the Nino Conis Santana National Park is not a pristine wilderness, nor does it contain rare or endangered fauna and flora. Rather, the so-called ecological values of the nominated park landscape are highly anthropogenic in origin. With the exception of birds, none of the animals found throughout the area encompassed by the park is endemic to Timor; they are all human introductions brought from areas to the east or west during the late prehistoric or historical periods. And, as I have already discussed, much, if not all, of the forested landscape of the park has been altered 
and shaped by thousands of years of human occupation and use. With very few exceptions, this is the situation found throughout Timor-Leste. For example, Metzner, commenting on the Baucau and Viqueque areas, states that ' $[a]$ very high proportion - probably as much as 90 per cent - of the vegetation of the area has been modified by man. As a consequence of repeated cutting, burning, cultivation and grazing it is hard to recognize the distribution of natural vegetation today' (1977:52).

To some extent, the identification of the proposed park as a 'Category V Protected Landscape/Seascape' is capable of recognising this human-environment interaction and its long history. According to the Guidelines for Protected Area Management Categories of the International Union for Conservation of Nature (IUCN 1994:22), 'Protected Landscapes/Seascapes' are defined as an '[a]rea of land, with coast and sea as appropriate, where the interaction of people and nature over time has produced an area or distinct character with significant aesthetic, ecological and/or cultural value'.

While key management objectives for 'Category V Protected Landscapes/ Seascapes' include the maintenance of the 'harmonious interaction of nature and culture', providing support for 'lifestyles and economic activities which are in harmony with nature' and the 'preservation of the social and cultural fabric of the communities concerned' (IUCN 1994:22), away from the noble intentions and rarefied spaces of the UN Educational, Scientific and Cultural Organisation (UNESCO) in Paris, and on the ground in Tutuala, the situation is not so harmonious or interactive. Fataluku people have already been told by local government authorities - obviously unaware of the UNESCO provisions regarding the preservation of lifestyles and support for economic activitiesthat hunting and gathering in the proposed national park area are now illegal. In banning this dimension of local Fataluku productive practices, the actions of the National Government appear to be focused upon producing the same social effects as previous colonial regimes - notably, the creation of dedicated agrarian communities. Government prohibition of hunting and gathering in the new national park not only has the potential to adversely affect the kind of subsistence flexibility that has enabled local people to deal with chronic environmental uncertainty and acute political instability, but it also seems to be blind to the important micro-strategic role this back-and-forth social movement between garden and forest played in securing the new nation-state of TimorLeste. While it might seem that the establishment of the new national park, and the bundle of state regulations associated with it, has rendered the task of producing locality even more of a struggle for Fataluku speakers in the Tutuala area, to date the lack of an active management regime for the park and the near absence of enforcement measures have effectively meant continuation of many of the 'banned' activities, albeit now under a communal veil of clandestine 
operations. With recent talk of the decentralisation of state power, and with it the emergence of more opportunities for local input into policies and decision making at the regional level, the potential exists for Fataluku people to once again reclaim the spaces and places so intrinsic to productive action and cultural identity.

\section{Acknowledgments}

The research on which this chapter is based was supported by an Australian Research Council Large Grant, and, in Australia, was conducted under the auspices of The Australian National University and the Rainforest Cooperative Research Centre, James Cook University. In Timor-Leste, research was undertaken under the auspices of the Ministero da Educacau, Cultura, Juventude e Esporto, and I would like to extend my general thanks and appreciation to the ministry staff who assisted me in the course of this research. Particular thanks go to the Ministerial Secretary of State, Senor Virgilio Simith, for his warm and muchwelcomed support. I would also like to acknowledge that without the support of the people of Tutuala this research would not have been possible. In this regard, I am particularly indebted to Senors Rafael Quimaraes, Custodio Quimaraes, Pedro Morais and Mecario de Jesus for their intellectual input, constant interest and warm friendship while in the field. I would like to acknowledge the invaluable support of my close friends and co-field researchers Sue O'Connor, from The Australian National University, and Peter Lape, from the Burke Museum, University of Washington. Finally, this chapter has benefited from the comments and suggestions made by the volume editor, Andrew McWilliam.

\section{References}

Almeida, A. de 1957, 'Hunting and fishing in Timor', in Proceedings of the Ninth Pacific Science Congress, Bangkok 1957. Volume 3: Anthropological and social sciences, Secretariat, Ninth Pacific Science Congress, 1963, Bangkok, pp. 239-41.

Andaya, L. Y. 1991, 'Local trade networks in Maluku in the 16th, 17th and 18th centuries', Cakalele, vol. 2, no. 2, pp. 71-97.

Anderson, R. and Deutsch, C. (eds) 2001, Sustainable Development and the Environment in East Timor, Proceedings of the Conference on Sustainable Development in East Timor, 25-31 January 2001. 
Appadurai, A. 1996, Modernity at Large: Cultural dimensions of globalization, University of Minnesota Press, Minneapolis and London.

British Broadcasting Corporation (BBC) n.d., 'Country profile-East Timor', BBC World News Service, Asia-Pacific.

Collins, Sean, Xisto Martins, W. M., Mitchell, Andrew, Teshome, Awegechew and Arnason, John T. 2007, 'Fataluku medicinal ethnobotany and the East Timorese military resistance', Journal of Ethnobiology and Ethnomedicine, vol. 3, no. 5, pp. 1-10.

Dames, M. L. (ed.) 1921, The Book of Duarte Barbosa, The Hakluyt Society, London.

Dove, M. 1983, 'Theories of swidden agriculture and the political economy of ignorance', Agroforestry Systems, vol. 1, no. 3, pp. 85-99.

Dunn, J. 1983, Timor: A people betrayed, Jacaranda Press, Milton, Qld.

Earl, G. W. 1853, The Native Races of the Indian Archipelago: Papuans, H. Bailliere, London.

Echols, J. M. and Shadily, H. 1990, Kamus Indonesia Inggris: An IndonesianEnglish dictionary, PT Gramedia, Jakarta.

Ellen, R., Parkes, P. and Bicker, A. 2000, Indigenous Environmental Knowledge and its Transformations: Critical anthropological perspectives, Harwood Academic Publishers, The Netherlands.

Forbes, H. O. 1989, A Naturalist's Wanderings in the Eastern Archipelago, Oxford University Press, Singapore, Oxford and New York.

Forman, S. 1981, 'Life paradigms: Makassae (East Timor) views on production, reproduction and exchange', Research in Economic Anthropology, vol. 4, pp. 95-110.

Fox, J. J. 1977, Harvest of the Palm: Ecological change in eastern Indonesia, Harvard University Press, Cambridge, Mass.

Fox, J. J. 2000, 'Tracing the path, recounting the past: historical perspectives on Timor', in James J. Fox and Dionisio Babo Soares (eds), Out of the Ashes: Destruction and reconstruction of East Timor, Crawford House Publishing, Adelaide, pp. 1-30. 
Friedberg, C. 1977, 'The development of traditional agricultural practices in western Timor: from the ritual control of consumer goods production to the political control of prestige goods', in J. Friedman and M. J. Rowlands (eds), The Evolution of Social Systems, Duckworth, London, pp. 137-71.

Friedberg, C. 1979, 'Socially significant plant species and their taxonomic position among the Bunaq of central Timor', in Roy F. Ellen and David Reason (eds), Classifications in Their Social Context, Academic Press, London, pp. 81-103.

Friedberg, C. 1989, 'Social relations of territorial management in light of Bunaq farming rituals', Bijdragen tot de Taal-, Land-en Volkenkunde, vol. 145, Part I: Nusa Tenggara Timur, no. 4, pp. 548-63.

Geertz, C. 1963, Agricultural Involution: The processes of ecological change in Indonesia, University of California Press, Berkeley, Los Angeles and London.

George, Kenneth. 1996. Showing Signs of Violence: The cultural politics of a twentieth-century headhunting ritual. University of California Press: Berkeley, Los Angeles and London.

Glover, I. 1986, Archaeology in Eastern Timor, 1966-67, The Australian National University, Canberra.

Grant, B. 1964, Indonesia, Penguin Books, Harmondsworth, UK.

Grey, G. 1841, Journal of Two Expeditions of Discovery in Northwest and Western Australia, 1837-39. Volume 1, T. \& W. Boone, London.

Gunn, G. C. 1999, Timor Loro Sae 500 Years, Livros do Oriente, Macao.

International Union for Conservation of Nature (IUCN) 1994, Guidelines for Protected Area Management Categories, International Union for Conservation of Nature, Gland, Switzerland, and Cambridge, UK.

Josselin de Jong, J. P. B. de 1937, Studies on Indonesian Culture. Volume I: Oirata-A Timorese settlement on Kisar, Foris, Amsterdam.

King, M. 1963, Eden to Paradise, Travel Book Club, London.

Kolff, D. H. 1840, Voyages of the Dutch Brig of War Dourga, Through the Southern and Little-Known Parts of the Moluccan Archipelago and Along the Previously Unknown Southern Coast of New Guniea Performed During the Years 1825 and 1826, James Madden \& Co., London.

Lape, P. 2006, 'Chronology of fortified settlements in East Timor', Journal of Island and Coastal Archaeology, vol. 1, pp. 285-97. 
McWilliam, A. 2001, 'Prospects for the sacred grove: valuing lulic forests on Timor', Asia Pacific Journal of Anthropology, vol. 2, no. 2, pp. 89-113.

McWilliam A, 2002, Paths of Origin, Gates of Life: A study of place and precedence in southwest Timor, KITLV Press, Leiden, Netherlands.

McWilliam, A. 2003, 'New beginnings in East Timorese forest management', Journal of Southeast Asian Studies, vol. 34, no. 2, pp. 307-27.

McWilliam, A. 2006, 'Fataluku forest tenures in the Conis Santana National Park in East Timor', in Thomas Reuter (ed.), Sharing the Earth, Dividing the Land: Land andterritory in the Austronesian world, Pandanus Books, Canberra, pp. 253-75.

McWilliam, A. 2007, 'Austronesians in linguistic disguise: Fataluku cultural fusion in East Timor', Journal of Southeast Asian Studies, vol. 38, no. 2, pp. 355-75.

Martins, J. R. 2001, 'Development of forestry conservation', in Sustainable Development and the Environment in East Timor. Proceedings of the Conference on Sustainable Development in East Timor, 25-31 January 2001, pp. 31-3.

Metzner, J. 1977, Man and Environment in Eastern Timor: A geo-ecological analysis of the Baucau-Viqueque area as a possible basis for regional planning, Monograph No. 8, Development Studies Centre, The Australian National University, Canberra.

O'Connor, S. and Veth, P. 2005, 'Early Holocene shell fish hooks from Lene Hara Cave, East Timor establish complex fishing technology was in use in island South East Asia five thousand years before Austronesian settlement', Antiquity, vol. 79, no. 304, pp. 249-56.

Ormeling, F. J. 1956, The Timor Problem: A geographical interpretation of an underdeveloped island, J. B. Wolters, Groningen, The Netherlands, and Jakarta.

Pannell, S. 2006, 'Welcome to the Hotel Tutuala: Fataluku accounts of going places in an immobile world', The Asia Pacific Journal of Anthropology, vol. 7, no. 3, pp. 203-21.

Pannell, S. and O'Connor, S. 2005, 'Toward a cultural topography of cave use in East Timor: a preliminary study', Asian Perspectives, vol. 44, no. 1, pp. 193-206.

Povinelli, E. A. 1993, Labor's Lot: The power, history and culture of Aboriginal action, University of Chicago Press, Chicago and London. 
Said, E. 1993, Culture and Imperialism, Vintage, London.

Soares, D. B. 2001, 'East Timor: perceptions of culture and environment', in R. Anderson and C. Deutsch (eds), Sustainable Development and the Environment in East Timor, Proceedings of the Conference on Sustainable Development in East Timor, 25-31 January 2001, pp. 18-21.

Therik, T. 2000, 'The role of fire in swidden cultivation: a Timor case study', in Jeremy Russell-Smith, Greg Hill, Siliwoloe Djoeroemana and Bronwyn Myers (eds), Fire and Sustainable Agricultural and Forestry Development in Eastern Indonesia and Northern Australia. Proceedings of an international workshop held at the Northern Territory University, Darwin, Australia, 13-15 April 1999, Australian Centre for International Agricultural Research, Canberra, pp. 77-80.

Traube, E. G. 1980. 'Mambai rituals of black and white', in James J. Fox (ed.), The Flow of Life: Essays on Eastern Indonesia, Harvard University Press: Cambridge, Massachusetts and London, pp. 290-317.

Traube, E. G. 1986, Cosmology and Social Life: Ritual exchange among the Mambai of East Timor, University of Chicago Press, Chicago and London.

Tsing, A. 1993, In the Realm of the Diamond Queen: Marginality in an out-of-theway place, Princeton University Press, Princeton, NJ.

Valeri, V. 2000, The Forest of Taboos: Morality, hunting and identity among the Huaulu of the Moluccas, University of Wisconsin Press, Madison, Wis.

van Engelenhoven, A. 1997, 'Words and expressions: notes of parallelism in Leti', Cakalele, vol. 8, pp. 1-27.

Wallace, A. R. 1872, The Malay Archipelago: The land of the orang-utan and the bird of paradise, Macmillan, London.

Weber, M. (ed.) 1902, Siboga-Expedite. Monographie I de: Uitkomsten Op Zoologisch, Botanisch, Oceanograpisch en Geologisch Gebied, E. J. Brill, Leiden, Netherlands. 